\title{
Investigating the Transit Oriented Development in New Urbanism, Case Study: Subway Stations Development in Mashhad
}

\author{
Saeid Rezvani Kakhki ${ }^{1} \&$ Mohammad Ajza Shokouhi ${ }^{2}$ \\ ${ }^{1} \mathrm{PhD}$ student, Department of Urban Planning, Ferdowsi university international branch, Mashhad, Iran \\ ${ }^{2}$ Associate professor of Geography, Ferdowsi University of Mashhad, Mashhad, Iran \\ Correspondence: Saeid Rezvani Kakhki, PhD student, Department of Urban Planning, Ferdowsi university \\ international branch, Mashhad, Iran. E-mail: rezvanibox1@gmail.com
}

Received: May 27, 2016

Accepted: June 8, 2016

Online Published: November 4, 2016

doi:10.5539/mas.v11n1p159

URL: http://dx.doi.org/10.5539/mas.v11n1p159

\begin{abstract}
New urbanism aims to reform the constructed cities as it seeks to create new and complete cities. The main idea of transit oriented development (TOD) is manly based on the public railroad transportation as the quickest and most effective tool in competition with automobiles (car) in order to cause an effective change in the transportation style and decrease the dependence on cars and horizontal growth of the city. In the current study, the experiences of the development corridors are analyzed after investigating the transit oriented development using applied descriptive method and the planning, capitalization and implementation methods are examined based on the corridor development theory. Types of land use suitable for development including residential, commercial, educational, leisure time and so are evaluated in terms of establishment and location. Next, the feasibility of implementation of this method in new spaces created by subway lines in the Mashhad city is studied. Investigation of one of the urban train lines shows that a station named Koohestan Park (mountain-park) located in the Vakil Abad Boulevard has appropriate potentials and advantages for corridor development and urban investments and can contain diverse land uses for orientation toward sustainable objectives. Finally, land use and market activity in the area around this station are investigated using the SWOT model and the necessity of investment and creation of corridor development unit is evaluated.
\end{abstract}

Keywords: accessibility, land use integration, new urbanism, TOD

\section{Introduction}

By the end of World War II, travel in the large cities was on foot or through transportation. Being close to the public stations was one of the important features of the real estate which was considered as the minimum walking distance. Stronger land uses such as stores, schools, employment centers, tend to settle in the vicinity of transit stations. Residential density across the streets with buses and public transportation increased and it decreased with increasing the distance from the stations. By emergence of automobile, the relation between the transportation and land use weakened, since many people start using cars and the effect of walking distance to the station declined (Lieberman, 1999). Horizontal urban growth with dependency to the automobile has long been criticized because of degradation of environment, social isolation and economic instability. Broad efforts have been done since 1970s for transmission from urban development patterns based on the car city which relied on the low density and suburb development of the separated land uses. Patterns based on the public transit and the pattern of corridor development was introduced to conduct the urban development around the public transportation. Hierarchical combination of transit systems including walking and riding and density, concentration and diversity of land uses around the major transportation lines caused the corridor development to be considered more than ever (Rahnama, 2013). Desirability of urban development in the vicinity of transportation facilities can be approved by effective promoting of accesses, life quality and financial sustainability of the public transportation systems. The basic idea of transit oriented development is that a suitable combination of transportation access, service efficiency and legible communication network for access to walking or cycling or avoid from using of cars can direct the smart urban growth to a life-giving society. But, when the land use- transportation relation (effective- impressible) is relatively spontaneous, this relation requires public support. Anyway, TOD is established based on the public railroad as the quickest and most effective tool in competition with automobile to cause an effective change in the transportation style and to decrease the 
dependency to automobile and horizontal growth (Greca et al., 2011).

In Europe, transport stations are not just as points for collecting the passengers, but act as a social center of excellence that encourage residents and sellers to use public transport by creating compact communities with different functions. Increasing the public transport in trips within the city, using the land use zoning and planning tools for easier access to the public transport and preventing the dispersion of the city, increasing the land use density (business and residential) and density distribution around the public stations are among main taken measures. TOD planning in every scale creates suitable opportunities for mixed dense development and can be introduces as an appropriate method to achieve an integrated model between land use pattern and transport planning around the stations and determining the sustainable manner of transportation in urban areas (Alizadeh, 2013). So that, direct relation is established between the public transport pattern and land use. The main idea was that more origin and destination points to be located in walkable distance from station and more people use the stations (Danesh \& Mozhdehi, 2008).This type of public transportation covers high density of population (at least 14 residential units per acre). Another superiority of TOD is that business institutes and other commercial uses are located around the transit centers. There are adequate walking and riding passages in the vicinity of the business centers. So that, more attention is paid to cars traffic and pedestrians. However, regional features of these transit centers ensure the formation of neighbor local centers like TND (Rahnama, 2012).

Mashhad is considered as one of the largest metropolises in Iran with 2800000 population and daily movement of 550000 passengers by bus and 170000 passengers by train and monthly movement of 3000000 people using urban train. Study and implementation of modern and efficient methods for urban development have been always among the main concerns of citizens and managers of the Mashhad. Therefore, the possibility of implementation of transit oriented development units in one of the urban train stations is investigated in the current study. Properties and indices of corridor development are examined using the applied descriptive method and feasibility of performance of this method is performed using SWOT model and required land use study in one of the high traffic stations of the urban train in the Mashhad.

\section{Research Method}

\subsection{Theoretical Principles}

TOD is an approach with emphasis on land uses around a station or transportation corridor and its specific features are as follows:

Combination of land uses

Average to high density

Orientation of pedestrians

Several options of the transportation

Parking decrease

High quality design

TOD is created within a $4 \mathrm{~m}$ radius area and with walking distance of 5-7 min from the transportation center. This method allows the transportation station involvement in the development. The approach often forms a new clustered development around one station in a wild or undeveloped land. It uses landscapes, urban furniture, street lighting and other features of the urban design to encourage the activity of pedestrians in linking the station with surrounding community. A necessary element of every successful development both in the city center or each smaller city or village is connection between roads network and adjacent land uses which are accessible by designing the landscape, sidewalks, roads, information pointers, buildings view, parking strategies and different kinds of land use. Historically, bus stations can't make TOD centers, because the routs and stations may change (EEA, 2007). Another attraction of the railroad transit is that people mainly prefer the train, since it is faster and more convenient than the bus. When the rail transit is available, most of people will not use their private cars. This also will create opportunities to construct and develop compact units in the vicinity of stations. Those people, who live in such compact areas, mostly pay fewer costs for transportation (Norquist, 1999). Obviously, suitable integration of land use and transportation planning affect the dependence to cars in the cities and help to reduce it (Cervero, 2002), distribution of owners' lands and economic activities and creates demand for different urban operations and then demand for travel. All movement options are influenced by properties of the transportation services (such as travel time, costs, reliability, convenience) which are available in origin and destination. Interaction of demand and travel creation determines the traffic current of different certain networks and accesses from land (Lgnaccolo, Capri, Giunta \& Inturri, 2006). Effective access to options of owners' 
position and economic activities creates circular relationship between the land use and transportation. The total pass $(\mathrm{km})$ travelled by bus is related to the total number of buses, travels sequence, length or travelled distance and the selected method. The last 3 cases are severely affected by land use. For example, access to commercial locations increases the travel repeat. When commercial locations are at short distant away from each other, the length of travel will be decreased and very close places can cause the type of travel to be changed into walking and attractions of the land use combination and urban design can influence the travel route.

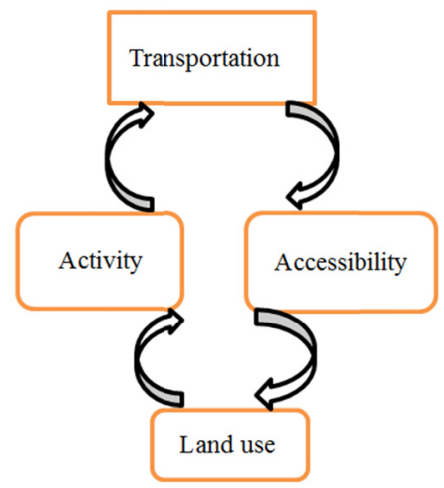

Figure 1. The relationship between land use and Transportation

Transportation planners focus on two main issues: first, a way through which changes in land uses can be made for better operation of the transport system. Second, method used to create desired changes in the transportation (Greca, et al, 2011). Land use density along with land use combinations, urban shape, urban design, activities scale, have generally great role in decreasing the travel by car and this role becomes possible by decreasing the travel repeat, travel distance and tend to other options of transport such as walking and cycling. This will lead to the new concept of transit oriented development. Establishment of new structures and reconstructions within and around the transportation stations by many researchers has been seen as a promising tool to halter horizontal growth and car expansion (TCRP Report, 102, 2004, p.3). How far is walking distance from a transit station? Several answers can be examined: residents cover one fourth mile $(400 \mathrm{~m})$ distance. Users will cover more distance to arrive rail and subway stations (one third or half a mile) or 600-800 m). Some points can be mentioned in this regard. Firstly, acceptable walking distance can change depending on the type of settlements. Walking distance can be increased in cities with high dependence on a secure transit system and attractive walking routs. Secondly, there are some evidence that users can tolerate more distances from transit stations to the home compare with the distance between the station and stores, work and other important destinations. Calthrope, defines the transit oriented development as a mixed collection in average $2000 \mathrm{ft}$. walking distance from station to business core. Combination of residential, commercial, administrative, open spaces and public use in the walkable environments of these spaces makes them appropriate for transport of residents and employees by public transit tools, bicycle and walking (Calthrope, 1993, p. 56). $2000 \mathrm{ft}$. is equivalent to $600 \mathrm{~m}$ to the station (Greca et al., 2011). The main idea was that more origin and destination points to be included in the walkable distance from station and more people use stations (Danesh \& Mojdehi, 2008). This kind of public transportation covers a very high density of population (at least 14 residential units per acre). Another superiority of TOD is that institutes and other business land uses are located around the passage centers. It covers this set of commercial centers using enough number of walk and ride route, so that more attention is attracted to the cars traffic and pedestrians. However, regional properties of this transit centers ensure formation of neighborhood local centers like TND model (Rahnama, 2011).

Many issues on corridor development focused on creation of residential development projects with different uses and sometimes include job creator uses in relative small dimensions. Meanwhile, more less attention is paid to the combination of leisure time, culture and work land uses toward the importance of main regional sites. These places are major employment centers and play great role in the economy health. Concentration of employment centers in the vicinity of transit stations can help expanding the job opportunities for those without cars such as low-income workers and generally better mobility and access to broader range of opportunities. Recent research of the Minnesota University showed that urban train stations increase the access of residents close to the station to low-income jobs around the station by $50 \%$ (Belzer et al., 2011). Commercial uses of neighbor units such as laundry, café and services including kindergarten can support the transit facilities due to being close to the get in/ get off places. When larger business facilities including shopping centers are close to the transportation facilities 
can convert to the transportation focal points. Key point for a transit station is establishment in vicinity of buildings entrance instead of locating near the parking lot. Schools in every level are ideal when located near the public transportation. In industrial uses, just thriving cases should be located near stations. Land use projects and zoning regulations that shows such uses and densities in the vicinity of available transportation lines or streets that becomes main paths in the future, have a long way ahead to convert urban spaces to sites in which transportation has active participation with environment. If public transportation can cover broad part of urban trips, urban areas can decrease the production of pollutants and fuel consumption and ignore more expenses of required buildings and infrastructures in horizontal growth patterns. Above all, when the transportation options increase and costs decrease, the life quality develops for citizens of metropolises (Lieberman, 1999).

Central station of Maryland in America: transit oriented development is depends on a strong public transportation system with high quality. Access to the transportation becomes more desirable with the growth of transit network and looks more useful in linking people to a place that they need to travel there in daily schedule (CMTA et al., 2009).

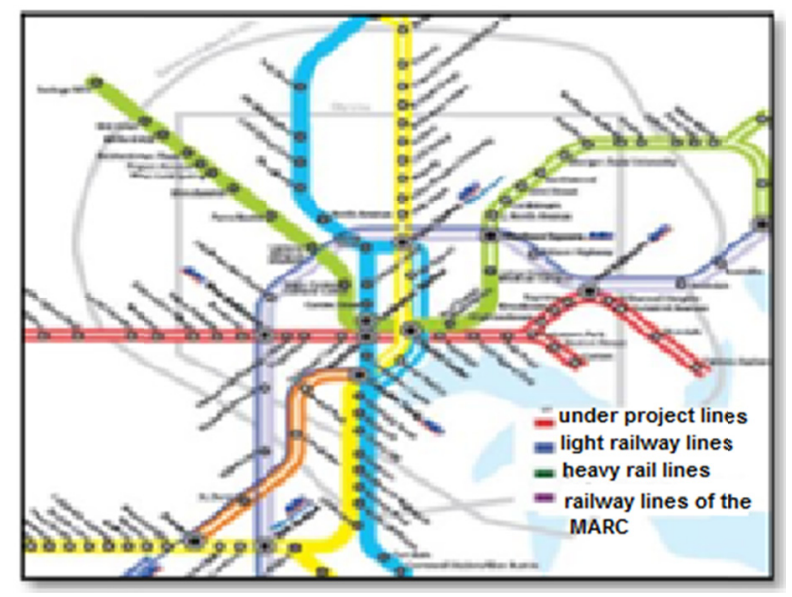

Figure 2. Strategic program of Maryland transit center in the Baltimore State in America

A transit system must link occupational, recreational and social destinations which present a level of access adequately to affect the development and to be able to compete with car ownership and using that. More importantly, trip destinations must lonely create remarkable opportunities, so that expansion of access to them can make real value for those who are near other stations of this system. TOD reinforcement in the central Maryland requires change in the intellectual system and common efforts for planning in different geographical scales and among various partners. The common efforts currently are emerging and need to be strengthened to implement recent developments (CMTA et al., 2009). Now, TOD is developed in the Owing mills and last stop in the subway line with the twenty-for hour high level of 4700 passengers is considered as the second high traffic station of the city. Owing Mill is determined as the growth center and needed decisions have been adopted to develop 18-acre site in vicinity of the transit station. 15.1 million $\$$ and 13.1 million $\$$ investments are adopted by Maryland transit organization and state organization. Moreover, 16-20 million $\$$ are provided by the state organization for state college and public facilities of library. This station created collaboration between Baltimore state Maryland transportation organization and private companies called subway system. Development with different uses around station was formed with the design form of the city center. The land use combination includes $112000 \mathrm{~m}^{2}$ administrative spaces, 495 residential units, 21000 commercial spaces, restaurant, $3700 \mathrm{~m} 2$ public library, $5600 \mathrm{~m} 2$ training space of the Baltimore state college, 250 hotel rooms, and 5 parking spaces including 11130 parking places. Site lands and properties belong to the Maryland transportation organization (MARC) and is offered to rent for 99 years for development and transformed to the capital asset for long-term profitability. The process of this huge urban planning was initiated for corridor development of neighbor zones with social, economic and environmental studies in these areas. Study scopes were determined at first by $400 \mathrm{~m}$ radius circles with a station in the center. Above mentioned areas are studied in terms of employment status, income level, social and economic needs of residents and field works have been done. Next, basic tables and maps are prepared on this basis. After examining all effective indices in stations and scoring all privileges, a total score is obtained from every station that would be prepared for final decision making on the investment rate and prioritizing. Finally, a development corridor can be planned and introduced considering the proximity to suitable 
stations with high investment capacity (CMTA et al., 2009).

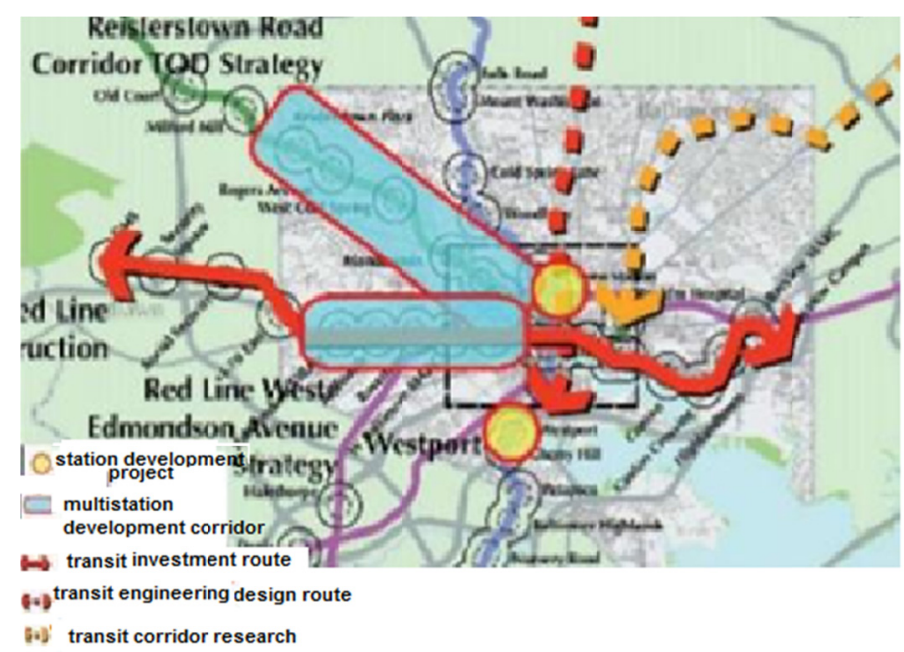

Figure 3. Development corridor project map in the Maryland urban train axis

\section{Research Results}

\subsection{Examining the Possibility of Corridor Development in Stations of the Urban Train in Mashhad}

The Mashhad city has $700 \mathrm{~km}$ passages within the city and 300000 private vehicles. Currently, 170000 passengers are daily transported using urban train of the Mashhad (transportation industry, 2014). This city has 3.5 million transportations every year and it will reach to the 5 million per day during 10 next years. Comprehensive studies of the Mashhad transportation during 1994-1999 and studies on development of rail transport during 2002-2004 were done by the transportation research institute of the Sharif University of Technology. According to the studies, Mashhad needs four subway lines and the studies are approved in the Traffic Council of the province and were introduced in higher council of traffic in cities of Iran country. Considering the presence of new cities such as Golbahar in the north and Binalood in the south, expansion of subway lines to these cities is also predicted and it passed the approval process. Based on the expressions of the research team of the project, investment method is in the form of using of financial credits and based on the Sharif university studies, if this project is implemented, it will attract almost $30 \%$ of the travels within the city (Hamshahri, 2009). According to the comprehensive studies of the Mashhad transport, total daily trips of this city equals to 3663354 in 2006 and 4244504 in 2011 and will be beyond 5200000 daily trip in 2016 and if urban train line in daily trips is not replaced, production of $\mathrm{CO}$ in peak days will reach from 56 ton per day in 2011 to higher than 82 ton in 2025 (Sanati Sharif, 2008). Vakilabad Boulevard is considered as one of the most popular routs attractive for trip in the city.

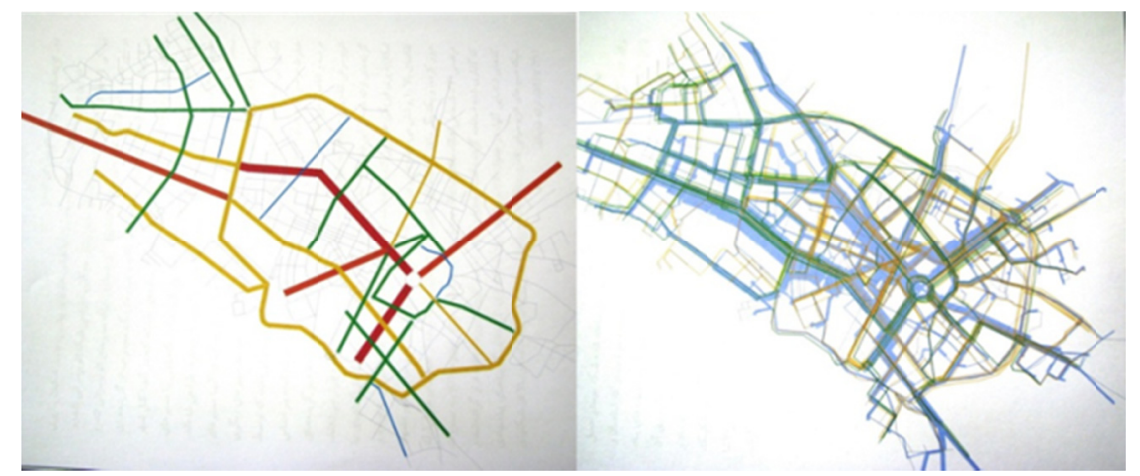

Figure 4. Designing the specific bus and other public transit means (Sanati Sharif, 2008)

Route of line 1 of the Mashhad urban train is from Shahid Hasheminejad airport to the end of Vakilabad Boulvard with the length of $25 \mathrm{~km}$. executive operations of $19 \mathrm{~km}$ of this route (Nakhrisi to Vakilabad) started from December, 2008 and $10.5 \mathrm{~km}$ of this route with passed in a shallow underground tunnel and $8.5 \mathrm{~km}$ in a flat 
route. In the primary $9 \mathrm{~km}$ which starts from the end of Nakhrisi Street, there is next lines stand (maintenance center) at the beginning of central stand (Depo-East) in addition to the stand of line 1 (Mashahd and suburbs train, 2014).

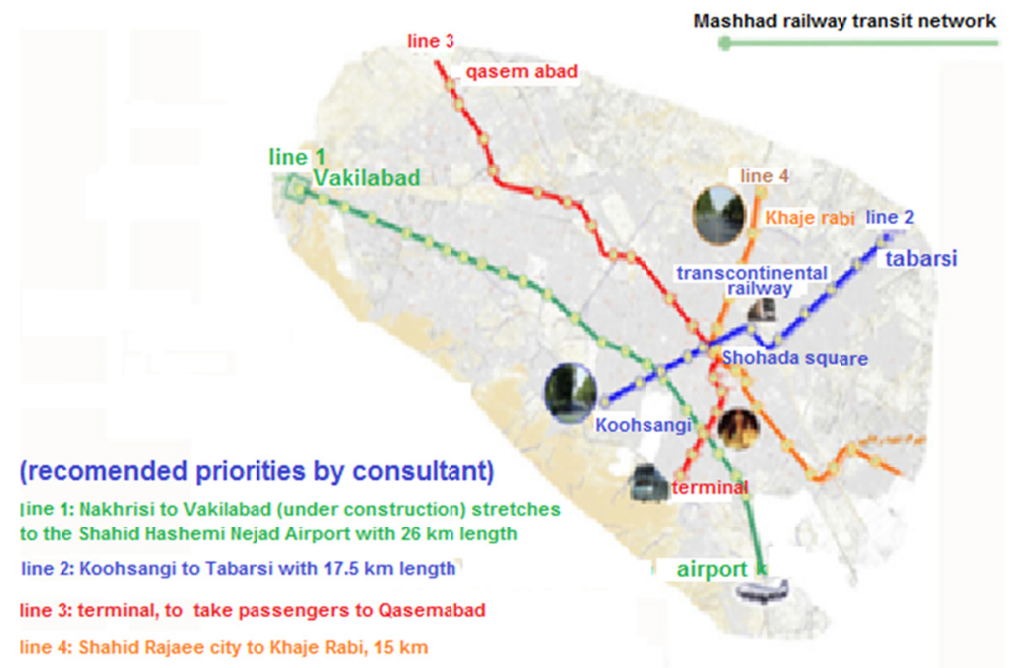

Figure 5. General scheme of the rail lines system in Mashhad (Mashhad and suburbs train, 2014)

This line cuts the line 2 in the Taqiabad Square. Route length is $19 \mathrm{~km}$ from east to west and vice versa and contains 22 stations including 11 subway station and 11 ground stations. Maximum speed of train is $80 \mathrm{~km} / \mathrm{h}$ and average speed is $36 \mathrm{~km} / \mathrm{h}$. the capacity of passenger transport is 20000 people per hour in every direction and the area of acquisitioned lands is 46 hectares. Ground stations in the route of Mellat Park to Vakilabad include 11 stations as follows:

Mellat Park, Kosar, Hashemie, Daneshamuz, Daneshjoo, Sadaf, Tarbiat, Eqbal Lahoori, Namayeshgah, Koohestan Park, vakilabad.

According to the data published from Mashhad urban train company, only economic activities and auctions in above mentioned stations include independent business units which are located inside the station space and will not significantly affect the environment around the station. For example, only one business unites with $12 \mathrm{~m} 2$ area is observed in the auction table of the urban train in the direction of Koohestan park station. According to the principles of TOD, a space with $400 \mathrm{~m}$ radius can be considered for every station based on the walkable form. These forms for the line 1 of the urban train in the Vakilabad Boulvard axis can be seen in the Figure 4.

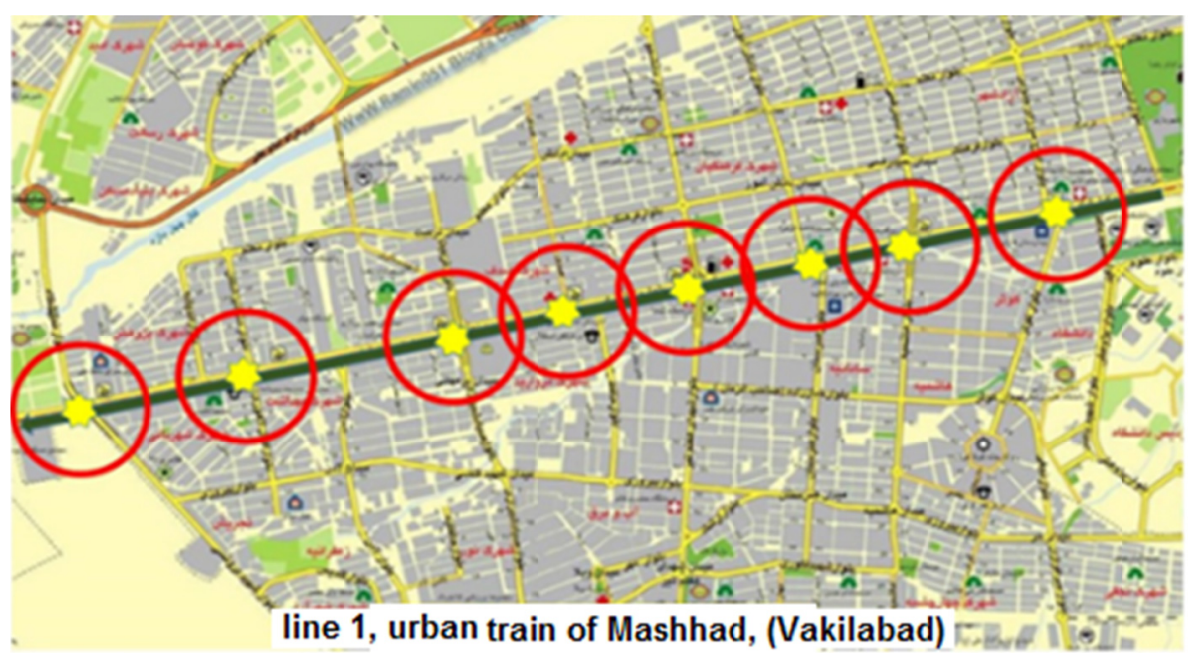

Figure 6. Primary scheme of the developable transit oriented units in the route of Mashhad Vakilabad urban train 
Scrutiny of development unit in the form of walking with $400 \mathrm{~m}$ radius and designing the suitable surfaces for establishment of mixed land uses in harmony with economic status and directing some activities and residential complexes toward these centers, it is possible to achieve mentioned policies in TOD. For instance, last stations, especially Koohestan Park are investigated considering the area of wild and undeveloped lands of this rail route.

\subsection{Investigating the Koohestan Park Station}

It is penultimate station in the Valilabad Boulvard route located in the three-way of the Vakilabad Torqabe Shandiz before the Partoee Bridge. Mountain park and amusement park lands are in the southern side of the station and there are large wild lands after them which lead to the Pardis town. In the northern side, there are wild lands belongs to the Saderat Bank and Vakilabad city after Namayeshgah Boulvard and some wild lands are in the vicinity of the city.

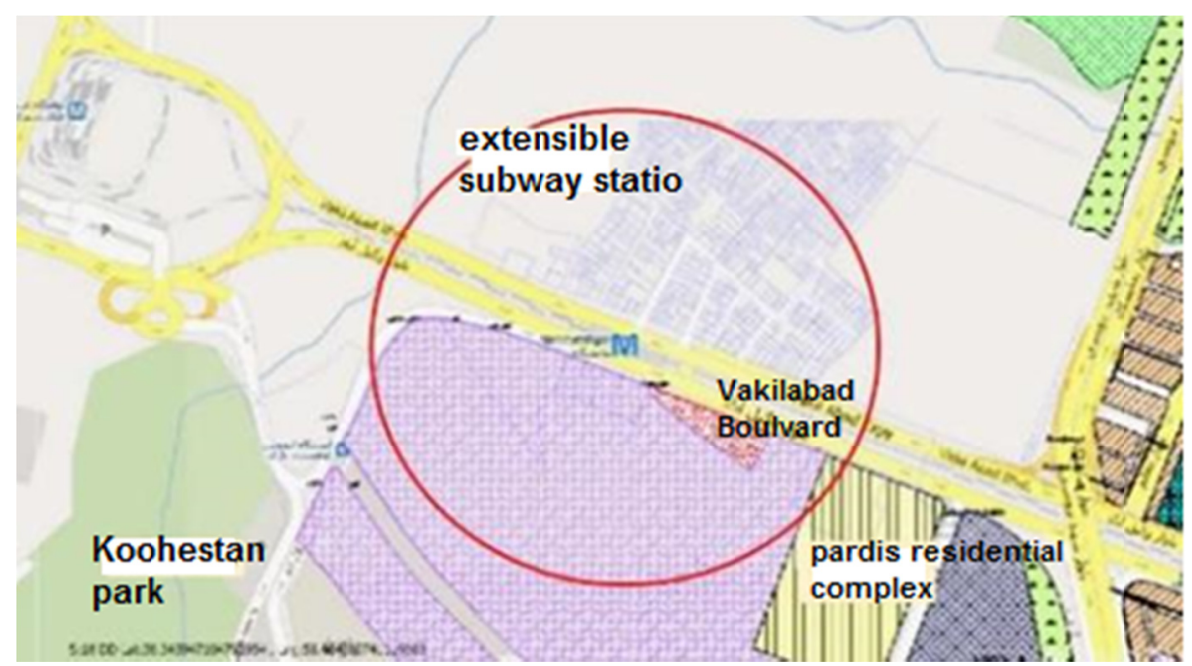

Figure 7. A sample of developable surface (with $400 \mathrm{~m}$ radius) around the Koohestan park station for TOD (municipality, 2014)

Lands in the southern side of the station are often wild (unutilized) with touristic land use and the price of northern lands around the industrial town of Vakilabad have not yet increased remarkably for several reasons and have not been not entered the Stock Exchange.

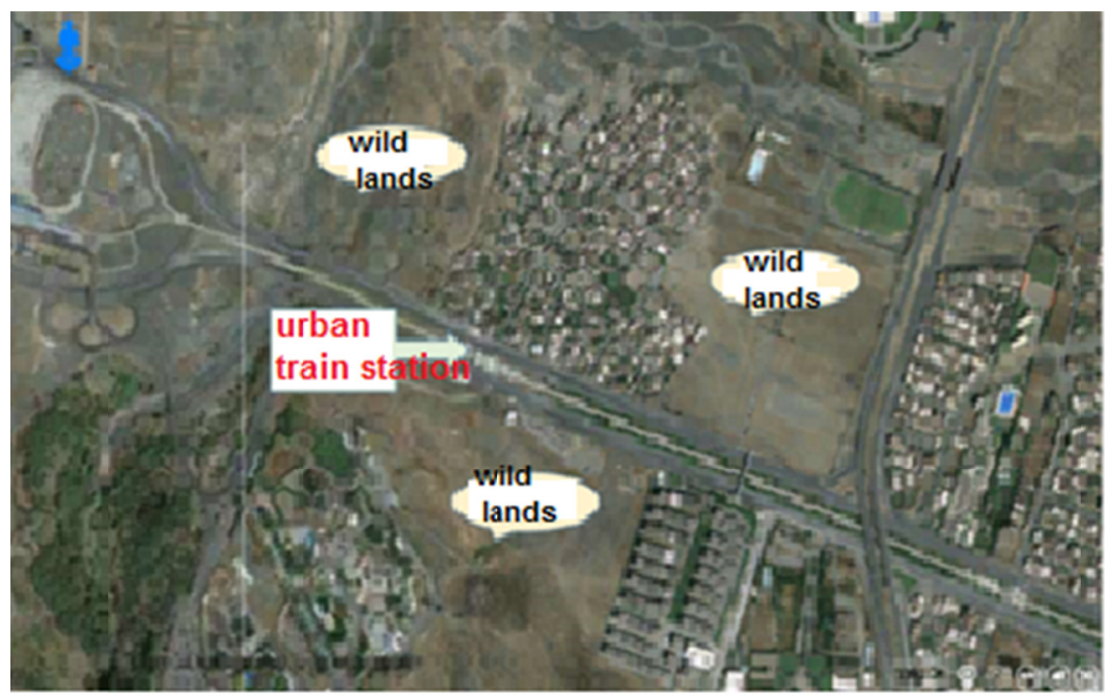

Figure 8. Aerial image of the station site and location of surrounding areas

Vakilabad city with almost organic and rural texture and 18-19 hectares area is located in the northern side of the 
station and upstream of the rail route of the urban train. In the eastern part of the station, there are wild lands with 18 hectares area between the Namayeshgah Boulvard and Vakilabad city that its land use was mentioned in the master residential plan. In the western part, theer are wild lands with less than 18 hectares area and relatively high slope between residential lands and coastal route of the river. Touristic land use is considered for them. There are large wild lands in the southern side of the urban train rail stretching up to the Vakilabad mountain ranges and Koohestan Park. They have touristic land use and the area equals to 37 hectares. These lands lead to the Vakilabad Boulvard from north, to Koohestan Park from south, to residential complex of Pardis from east, to Vakilabad Park and river from west.

The corridor development unit opportunity is evaluating the development unit potential in a given station. There are two key sets of indices to evaluate opportunities:

The opportunity of lands: if there are lands available for development, in the form of wild lands, previously developed lands or public property.

Market activity: if there was previously business activity in the form of construction permits, increasing the sell or rental amount or high volume of transactions for development activity?

Analysis of Koohestan Park station condition is summarized in the SWOT table.

Table 1. SWOT table, land uses and market activity in the koohestan park station

\begin{tabular}{|c|c|c|c|c|}
\hline field & strength & weakness & opportunity & threat \\
\hline $\begin{array}{l}\text { Lands and } \\
\text { land uses }\end{array}$ & $\begin{array}{c}\text {-Prediction of } \\
\text { Spending leisure time } \\
\text { land uses in detailed } \\
\text { scheme in vicinity of the } \\
\text { station } \\
\text {-Presence of } \\
\text { residential } \\
\text { complex in the design } \\
\text { range } \\
\text {-Proximity with rail } \\
\text { transit axis as powerful } \\
\text { agent of urban access } \\
\end{array}$ & $\begin{array}{l}\text { Presence of urban } \\
\text { organic and } \\
\text { worn-out texture } \\
\text { of the Vakilabad } \\
\text { in the northern } \\
\text { part }\end{array}$ & $\begin{array}{l}\text {-Wide wild lands, ready } \\
\text { for development } \\
\text {-Natural landscape of the } \\
\text { lands surrounding the } \\
\text { station } \\
\text {-Proximity to the } \\
\text { Vakilabad forest park and } \\
\text { Koohestan Park }\end{array}$ & $\begin{array}{c}\text { Lack of urban } \\
\text { equipment and } \\
\text { installations in the } \\
\text { southern side due to } \\
\text { lack of } \\
\text { development }\end{array}$ \\
\hline $\begin{array}{l}\text { Market } \\
\text { activity }\end{array}$ & $\begin{array}{l}\text { Welcoming the } \\
\text { Koohestan Park and } \\
\text { Vakilabad Park in the } \\
\text { urban scale }\end{array}$ & $\begin{array}{l}\text { Lack of attractive } \\
\text { settlements after } \\
\text { the Koohestan } \\
\text { Park station in the } \\
\text { route } 1 \text { of the } \\
\text { urban train }\end{array}$ & $\begin{array}{l}\text {-Presence of major } \\
\text { owners in a part of } \\
\text { northern lands } \\
\text {-Presence of topography } \\
\text { attractions and natural } \\
\text { landscape in the region }\end{array}$ & $\begin{array}{l}\text { Financial weakness } \\
\text { of residents of } \\
\text { Vakilabad city in } \\
\text { some parts }\end{array}$ \\
\hline
\end{tabular}

\section{Conclusion}

TODs are ability to direct development to the prone urban points in addition to the focus on walking and public transportation. Many powerful new facilities are created along with the traffic privileges in citizens' transport by public means through the capable rail transit system for urban development and job creation in cities. In Mashhad city which is considered mainly as a pilgrimage city with touristic services in which the importance of TODs looks more than other cities. Hence, increasing the economic and social studies in the margin of urban railway and directing the investments to new corridor systems are extremely effective in revitalizing and strengthening the development projects and using successful experiences of many developed countries for progress and job creation in metropolises. Investigating the first railway of the Mashhad shows that stations located at the end of route (Koohestan Park station) is able to establish corridor development with suitable privileges because of strong characteristics and potentials.

\section{References}

Alizadeh, H., \& Abdi, M. H. (2013). Effective factors on travel pattern of the citizens using TOD approach, urban and regional research and studies, Sannadaj.

Bahrami, A. S. (2011). Growing importance of secondary incomes for financial supply of public transportation, 
Milan journal, Mashhad Urban and Suburban Railway Company.

Belzer, D., \& Srivastava, S. (2011). Transit-Oriented Development and Employment [Book Section]. Center for Transit-Oriented Development.

EEA Energy \& Environmental Affirs Smart Growth/Smart Energy Toolkit (2007-2014). http://www.mass.gov/envir/smart_growth_toolkit/ed. website Governor Patrick's

Greca P., et al. (2011). The density dilemma. A proposal for introducing smart growth principles Cities-Elsevier. pp. 527-535.

Hamshahri News. (2009-2014). Online, Hamshahri.

Lieberman, W. (1999). Chapter of the new urbanism, McGraw-Hill, Inc.

Mashhad Municipality. (2012). Retrieved from: http://esup.mashhad.ir, internet services of the integrated urban development system of the Mashhad municipality

Mashhad Urban and Suburban Railway Company (2014). Musroc.ir, Mashhad Urban railway.

Mashhad Urban railway, Economic and planning unit (2009). Mashhad Urban railway Company.

Norquist, O. J. (1999). Charter of the new urbanism. McGraw-Hill, Inc.

Pittsburgh Community Reinvestment Group. (2013). CTOD Center for Transit-Oriented Development Transit-Oriented Development Typology Strategy for Allegheny County [Book Section].

Rahnama, M. R. (2013). corridor development in Melbourne metropolitan region.

Rahnama, M. R., \& Abbaszadeh, G. (2008). Principles, foundations and models of physical form of the city measurement, Mashhad, Jahad Daneshgahi.

Rahnama, M. R., Roshani, P., \& Afshari, M. (2012). Improving the quality of modern urban districts using new urbanism approach, geography and urban development, No 3.

Sarafi, M., \& Mohamadian, H. M. (2014). Feasibility study of sidewalk construction in streets of the Hamadan city center, environmental preparation quarterly journal, Tehran, 21, p.116. Transport industry of the analytic news station, Tinn news, November 3.

Sharif University of Technology and Center for Transportation Research (2008). Comprehensive studies of the Mashhad transport (report), Mashhad, Mashahd Traffic Organization.

Zimbabwe, S., Austin, M., \& Belzer, D. (2009). CMTA Central Meryland Transportation Aliance and CTOD Center for Transit-Oriented Development Central Maryland TOD Strategy [Book Section]. Retrieved from http://www.cmtalliance.org

\section{Copyrights}

Copyright for this article is retained by the author(s), with first publication rights granted to the journal.

This is an open-access article distributed under the terms and conditions of the Creative Commons Attribution license (http://creativecommons.org/licenses/by/4.0/). 